\title{
Kvinna i den kulturelle bibelen Ein analyse av nyare norske barne- og ungdomsbiblar
}

\author{
Av Ingunn Aadland
}

I denne artikkelen undersøker eg korleis kvinner er representert i den norske kulturelle bibelen med utgangspunkt i gjenforteljingane av Det nye testamentet $i$ barnebiblar utgjevne det siste tiåret. Eit hovudfunn i bibelresepsjonen er at barnebiblar prioriterer forteljingar der menn er hovudpersonar. Vidare finn eg to hovudtendensar i dei forteljingane der kvinner er sentrale: 1) deira rolle er nedprioritert og marginalisert, 2) der kvinner si rolle er framheva, er dei presentert som synderinner. Eg hevdar ikkje at desse fortolkingane er medvitne uttrykk for kvinneforakt. Snarare reflekterer dei ein lojalitet overfor den kulturelle bibelen, det vil seie bibelen slik den vert hugsa og forstått $i$ vår kultur, og like mykje ei manglande erkjenning av rolla kulturen speler $i$ tolkinga av bibelen. Denne resepsjonen av bibelen er ikkje berre reproduksjon og aksept av antikkens ideal, men og uttrykk for verdiar $i$ vår eiga tid.

Nøkkelord: Bibel, kulturell bibel, barnebibel, resepsjon, kjønn

$$
\begin{gathered}
\text { IngunN AAdLAND (f.1981), Ph.D. Rådgjevar IKO-Kirkeleg pedagogiske senter, pb 2623, St. Hanshaugen, } \\
\text { o131 Oslo. E-post: ingunn.aadland@iko.no }
\end{gathered}
$$

\section{INNLEIING}

Bibelen er ikkje barnelitteratur. Dei fleste bibeltekstar må tilpassast slik at dei blir forteljingar som kan formidlast til barn. Men kva tekster vel vi for barn, og kva element ved bibelforteljingane er det som utløyser justeringsbehov i ein norsk kulturell samanheng? Når bibelen blir barnebibel, vert både innhaldsmessige og teologiske prioriteringar gjort. Tilpassingane, medvitne og umedvitne, seier noko om korleis bibelen vert forstått, og samstundes viser dei kva bibel som vinn fram i vår kultur. Slik er både utval forteljingar, og fortolkinga av desse, eit uttrykk for ein kulturell bibel. Utgangspunktet for å analysere barnebiblane, er altså tanken om at dei norske produksjonane faktisk reflekterer bibelen slik den står seg i vårt kulturelle minne.

Eit av funna i analysane mine (sjå nedanfor), er at kvinner kjem i bakgrunnen i barnebiblar. Dette må naturlegvis sjåast i samanheng med, og som eit resultat av bibelens patriarkalske grunnhaldning. Likevel vil eg påstå at slik bibelforteljingane vert fortalt i dag, i stor grad gir uttrykk for vår eigen kultur, og bibelen slik den vert forstått i vår tid.

Prismet - IKO-Forlaget 2019

Tilgjengelig på https://journals.uio.no/index.php/prismet. Publisert under CC BY-NC 4.0. Fagfellevurdert 
Det at Bibelen er påverka av sin samtidskultur, er ikkje noko nytt. Til dømes har Sør-Afrikanske Jeremy Punt vist korleis barnebiblar ikkje berre reflekterte, men forsterka, afrikaans nasjonalisme under apartheidstyret (Punt 2012: 73-98). Punt si studie er ein del av antologien Text, image, and otherness in children's Bibles: What is in the picture? Redaktørane for antologien seier i innleiinga: «Children's Bibles constitute the religious norms and moral values an adult community treasures and intends to impart to the next generation» (Stichele og Pyper 2012: 31). ${ }^{1}$

Som i samtida si historieskriving generelt, har namngjevne kvinner det med å bli fortrengt frå barnebibelforteljingane. I barnebibelen er dei bibelske kvinner først og fremst mødre, døtre eller potensielle koner. Bibelen gjev likevel nokre glimt av ei verd der kvinner ikkje berre finst, men er subjekt og har autoritet over eigne liv. Dei kan til dømes vere velståande vertinner, vener av Jesus, slik som Marta og Maria. ${ }^{2}$ I boka In Memory of Her, som i dag er blitt ein klassikar, påpeiker Elisabeth Schüssler Fiorenza (1988: xv) at det er naudsynt å supplere perspektiva som finst i Det nye testamente for å finne fram til desse kvinnene. Samstundes finst dei og i Bibelen. Tittelen på boka speler nettopp på ei bibelsk kvinne som har vorte gløymd i det kulturelle minnet, kvinna som salvar Jesus (Mark 14,3-9).

I resepsjonen av bibelen speler det kollektive minnet inn. Det kulturelle minnet er selektivt, fordi minnet i seg sjølv har ei naturleg avgrensing. Aleida Assman seier det slik: Kvar generasjon står på skuldrene til sine forgjengarar, og kan ombruke og omtolke den kulturelle kunnskapen (Assman 2008: 97). Det vår kultur definerer som viktig, får følgjer for kva bibel vi hugsar. Og det vi repeterer i det kollektive minnet, får følgjer for kunnskapen om kva bibelen er og inneheld (Sjå meir om dette i Larsen 2019, i dette nummeret av Prismet). Når Svein Tindberg skulle skrive ein barnebibel (Bibelfortellinger for barn, 2017) skriv han inn kvinner og jenter i forteljingane, men vi finn ikkje mange av bibelens eigne kvinner i denne. Dette har med den kulturelle kunnskapen om bibelen å gjere. For det kan virke som om bibelens kvinner har kome så langt inn i gløymselen, at vi ikkje registrerer at dei har vorte namnlause eller blitt borte frå forteljinga. Sjølv tretti år etter Fiorenzia si bok, er problemstillinga altså like aktuell. I barnebibelen går ein ikkje berre utover NT, men innskrenker perspektivet ved å gløyme dei kvinner som finst der. Det kan slik synast som om kvinna blir vurdert som mindre interessant og mindre teologisk viktig. Vidare er forteljingar om kvinner statistisk sett oftare knytta til synd (sjå nedanfor), utan at dette ser ut til å aktivere behovet for å justere perspektivet i forteljinga. På

1 Boka presenterer framstillingar av "andre» $\mathrm{i}$ tekst and illustrasjonar i barnebiblar: "These Bibles are vehicles for the transfer of what the adult religious collective considers to be long-standing, traditional, and universal and therefore essential to their belief system, their way of life, and also their identity,» 31 .

2 Sjølv om evangelia framstiller Marta og Maria som vertskap i eigne hus, legg IKO-Forlaget si barnebok «Marta, Marta» (2006) til at Lasarus er den som forsørgjer dei to. Dette er eit godt eksempel på korleis fantasien er styrt av eigen kultur, men samtidig og dei fordommar ein har om kva rolle bibelske kvinner kunne ha. Sjå t.d. Marianne Bjelland Kartzow's artikkel om kulturell kompleksitet (Kartzow 2010). 
bakgrunn av dette er framstillingane av kvinner i barnebiblane interessant frå eit \#Metoo-perspektiv. For kva grunnhaldningar er det som kjem til uttrykk i dette? Det at allmennkulturen tilsynelatande ikkje reagerer på marginaliseringa av dei bibelske kvinnene i barnebibelen, er ikkje det djupast sett eit uttrykk for ein kultur som aksepterer kvinneforakt?

Denne artikkelen presenterer sentrale trekk i framstillinga av kvinna, i eit utval nyare norske bibelbøker for barn og ungdom: Bibelfortellinger (IKO-Forlaget 2011), Saman med Jesus (IKO-Forlaget 2016), Tidslinjen (Verbum 2016) og Bibelfortellinger for barn (Stenersen forl. 2017).

\section{Barnebibelen OG DEN KULTURELle Bibelen}

Bibelen tar materielt sett mange former. Nokre bibel-representasjonar framstiller heile bibelen, slik som til d $\emptyset$ mes Bibelen (NO 2011), lydb $\emptyset$ ker og bibelappar. Andre bibel-format medfører at ein må gjere utval, slik som Den norske kyrkja sine tekstrekkjer, barnebiblar og andaktsb $ø$ ker. I norske barnebiblar finst eit utval forteljingar som kan seiast å utgjere ein «kanon i kanon.» Dette utvalet er forma av luthersk tradisjon, ${ }^{3}$ men også av internasjonale forlag som produserer biblar for barn. Kristin Moen Saxegaard referer til ein slik barnebibelkanon (Saxegaard 2009: 87). Slik eg ser det, utgjer ein slik barnebibelkanon meir enn eit utval eller ei liste av historier. Like viktig er måten desse vert tradert på. Særleg er dette tydeleg i påskeforteljinga, som er forteljingar som lever sine eigne liv i dramatiseringar og musikk. Det finst ein ide om kva bibelen handlar om, som reproduserer ein gitt måte å gjenfortelje bibelen på. Denne ideen viser seg altså både i utvalet av tekstar, men og korleis forteljingane i utvalet vanlegvis vert fortalt. Ein såkalla kanon i kanon, eller barnebibelkanon, heng tett saman med det eg vil kalle den kulturelle bibelen.

Eg bruker termen 'kulturell bibel' for å beskrive bibelen slik vi kjenner den i vårt kollektive medvit og slik den vert representert i til dømes barnebiblar. Sjølvsagt finst det eit spekter av ulike oppfatningar av kva bibelen er, og å referere til kulturell bibel i eintalsform er ei stor forenkling. Samstundes finst såpass mange fellestrekk i materialet at eg meiner det kan forsvarast. Nemninga, slik den opphavleg vert brukt av Jonathan Sheehan, viser til korleis opplysingstida sin bibel gjekk frå å vere eit teologisk til eit kulturelt verk (Sheehan 2005: 220). Der bibelen ifølgje teologien representerte «sanning», representerte den no i allmennkulturen litterære, pedagogiske og moralske kvaliteter. Resepsjonen av bibelen, i politikk og i kultur, har fătt aukande interesse hos bibelforskarar.4

3 Vektleggingane av sekvensar i lidingshistoria har røter i luthersk tradisjon, t.d. Martin Luthers Betbüchlein mit dem Calender und Passional frå 1529/1545, med 38 utsnitt frå NT. Her finst oppvekkinga av Lasarus, Jesus som rid inn i Jerusalem og fotvasking, men ingen kvinne som salver Jesus. Sjå faksimile i den digitale samlinga frå Bayerische Staatsbibliothek (https://www.bsb-muenchen.de).

4 I norsk samanheng har t.d Hilde Brekke Møller forska på Listhaugs bruk av Jesus i politisk retorikk jf. «The Power of Jesus: The Use and Significance of 'Jesus' in Norwegian Culture» (Møller: 2018) 
James Crossley bruker nemninga «Cultural Bible» i si forsking på bibelen i den britiske politiske diskursen. I ein aukande sekularisert kontekst og i ei tid med fallande bibelkunnskap lever ulike idear om kva bibelen eigentleg handlar om («what it really means»). Crossley bruker termen «cultural bible» for å seie noko om korleis bibelen blir sett på som ein kulturell klassikar, og eit stadig viktig kulturelt objekt (Crossley 2014: 10). I vår norske samanheng vil eg hevda at det ikkje gjev like god meining å snakke om bibelen i kulturen som noko fundamentalt annleis enn kyrkja sin bibel. Kyrkja sin bibel er i kontakt med allmennhetens bibel, og den kulturelle bibelen reflekterer nettopp ei kyrkjeleg tradering i kontinuerleg dialog med samtidskultur og samtidsverdiar. Den kulturelle bibelen vert då ei nemning for den bibel som er tilgjengeleg i det kollektive minnet, og som pregar både kyrkja og allmennheten si oppfatning av kva bibelen eigentleg handlar om. Men korleis er så denne bibelen?

\section{Norske barnebiblar: forsking OG UTGJEVINGar}

I barnebiblane vert bibelforteljingar tilpassa barnet. Dei fleste tilpassingane er av pedagogisk og teologisk art. Tidlegare forsking viser korleis krevjande gudsbilete vart tona ned (Saxegaard 2009), og framstillinga av heltefigurar vert forenkla (Afset 2011). På bakgrunn av dette har forskarar peika på behovet for å få fram eit breiare og meir komplekst tilfang av tekstar med eit større mangfald av gudsog menneskebilete. ${ }^{5}$ Men det er også slik at barnebibelen vert tilpassa for å imøtekomme barnekulturen og marknaden. Eit døme på dette er boka Prinsesser $i$ bibelen (Hermon Forlag 2014). Ifølgje Lerheim begrunna forlaget utgjevinga med eit $\emptyset$ nske om å fă fram dei mange ukjente kvinnene i Bibelen (Lerheim 2016:20). ${ }^{6}$

I artikkelen «Trosopplæring for Guds prinsesser» (Lerheim 2016) bruker Lerheim denne boka som case for å reflektere over bibelarbeid med barn. Lerheim teikner vidare opp eit bilete over forskinga på feltet. Ho viser korleis norsk forsking på bibelformidling særleg har vore opptekne med Det gamle testamentet og føreslår at det kan ha å gjere med GT sine dramatiske forteljingar og potensielt utfordrande gudsbilde og kjønnsforstång. I denne analysen har eg særleg valt å fokusere på bibelbøkene si gjenfortellingar av NT, som har fått tilsynelatande mindre kritisk merksemd av bibelforskarar. Kanskje fordi det er lettare å problematisere GT-forteljingane, slik Lerheim antyder. Så langt eg kjenner til, er det gjort ein del forsking på barnebiblar, der ein stiller spørsmålsteikn ved utval av forteljingar («en gitt barnebibelkanon») (Saxegaard 2009: 89). Men eit element ved dette er ikkje berre den statistiske representasjonen

5 I artikkelen «Jona som forbilde, karikatur eller speilbilde,» ender Afset opp med ein appell til å beholde eit brett teksttilfang, og bevare kompleksiteten (Afset 2011:148).

6 Dette er paradoksalt nok i tråd med ein feministisk strategi, «å leite fram kvinnelige aktørar og setje dei i sentrum» jfr. (Kartzow 2008:251). 
av såkalla kvinneforteljingar, men og sjølve framstillinga av dei kvinnelege karakterane som faktisk er med. Denne artikkelen tar sikte på å utforske nettopp det. Hovudspørsmåla i analysen er: Kva bibel er vidareformidla til barn og unge? Kva prioriteringar og omsyn vert tatt, med omsyn til utval og perspektiv, med særleg vekt på framstillingar av bibelske kvinner?

For å få eit bilete av den norske 'kulturelle bibelen,' har eg valt å avgrense materialet til norskproduserte bibelbøker for barn og unge det siste tiåret (20082018). Det er ikkje så mange som ein skulle tru, då mykje av det som vert utgitt, er samproduksjonar, eller omsetjingar der det ofte allereie ligg føringar på utval av forteljingar og illustrasjonane til dei. Det betyr til dømes også at Hermon forlag sine utgjevingar, sjølv om somme av dei er frie norske omsetjingar, ikkje er med her.7 I utvalet finst Bibelfortellinger (IKO-Forlaget), Tidslinjen (Verbum), Bibelfortellinger for barn (Stenersen forl.), og Saman med Jesus (IKO-Forlaget). ${ }^{8}$ Artikkelen gjev ikkje ein fullstendig presentasjon av dei ulike bøkene. Målet med analysen er heller ikkje å gi ei vurdering av den enkelte boka, men å sjå på korleis dei ulike bibelbøkene reflekterer bibelen sitt innhald med omsyn til framstillingar av dei bibelske kvinnene.

Bibelfortellinger, den eldste boka i utvalet, er ei omfattande bok på meir enn 400 sider, retta mot ungdom, «frå 14 år og oppover.» Det er altså ingen barnebibel. Bibelfortellinger plukker forteljingar frå alle evangelia, og ligg heile tida nær den bibelske ordlyden frå NO78. Sjølv om forteljingskronologien følgjer NO78, er bibelforteljingane likevel omorganisert, slik at boka presenterer ei bærande framstilling. Gjennomgåande finst eit medvit om å framheve kvinnelege karakterar. ${ }^{9}$ Likevel, i Bibelfortellinger sine 42 hovudoverskrifter frå NT er det faktisk berre tre som nemner kvinnelege hovudpersonar, og berre ei som namngjev kvinner. Desse er «Den samaritanske kvinna,» «Kvinna som vart tilgjeven, » og «Marta, Maria og Lasarus.» ${ }^{10}$ To av desse fire kvinnene er altså anonyme og forbunde med seksuell umoral.

Tidslinjen er ein barnebibel for alderen 6-9 utarbeida med tanke på trusopplæring. I permen til Tidslinjen finst ei illustrert tidslinje som kan brettast ut. Tilsvarande finst ei stor tidslinje som skal rullast ut på golvet. Denne bibelen skaper slik ein kronologi av bibelske forteljingar. Utvalet av gamaltestamentlege forteljingar vitnar om eit medvite kjønnsperspektiv, og både «Rebekka»

7 Teikneserieblad og aktivitetshefte er ikkje med. Heller ikkje reviderte produksjonar som kom i tilknyting til ny bibelomsetjing i 2016.

8 Eg har sjølv vore tilsett ved IKO - Kirkelig pedagogisk senter sidan våren 2016, og sjølv om eg ikkje er ansatt i IKO-Forlaget, medvirker eg som konsulent i bokproduksjonar. Eg har valt å ikkje framheve dei ulike forfattarane bak desse bibelbøkene, altså viser eg til tittelen på boka og forlag. Dette for å understreke at det er den kulturelle arven bøkene representerer som er av interesse i denne undersøkinga, ikkje den individuelle forfattaren.

9 Til dømes vert det fletta inn ein referanse til Mark 6,3 om Jesu søstre, i gjenforteljinga av Luk 4 (s. 327).

10 Med unntak av 'engel' og 'barna' og 'Emmausvandrerene', indikerer dei øvrige 36 mannlege hovupersonar, av desse er 16 unike individ, eller grupper (som 'disiplene', de tre vise menn). 
og «Rut» er eigne overskrifter i GT-delen av boka. ${ }^{11}$ I NT finst likevel berre to overskrifter som indikerer kvinnelege hovudpersonar, desse er «Jairus' datter» og «kvinnene ved graven.» Hovudvekta i utvalet tematiserer eigenskaper eller verbhandlingar ved Jesus. Av desse inngår kvinner i fleire av forteljingane. Særleg sentral vert kvinna gripen i hor i kapitlet «Jesus tilgir,» som har sin eigen illustrasjon i tidslinja.

Saman med Jesus fortel 15 korte forteljingar, med kvar sin illustrasjon. Boka er ein slags oppfylgjar av Bibelboka mi (2005) og må sjåast i lys av denne med tanke på utval. Denne boka har hovudsakleg med forteljingar frå NT, og berre to frå GT. Bibelforteljingane er sett saman tematisk, og følgjer berre delvis ein bibelsk kronologi. Misjonsbefalinga kjem først, og forteljingar som vanlegvis er assosiert med lidingshistoria, kjem til sist. Det er god kjønnsbalanse i namngjevingane og illustrasjonane i dei 15 overskriftene. Boka har med forteljinga om Marta og Maria, men dei vert likevel ikkje nemnt med namn i Lasarus-forteljinga (s. 48). Vidare fortel boka om synderinna som salvar Jesus, framfor fortelijnga om Maria som gjer det. ${ }^{12}$

Bibelfortellinger for barn har eit klassisk utvalg frå GT og NT, og innhaldslista nemner ingen kvinnenamn. Gjenforteljinga er langt friare enn i dei øvrige bøkene, og i gjenforteljinga av NT skriv Tindberg fram dei nye karakterene Joanna, Ariel, Bartimeus og Cora. Forteljinga vekslar mellom fokus på dei bibelske hendingane og barna si oppleving knytta til desse.

Dei fire ulike bibelbøkene har altså stor variasjon når det gjeld format og målgruppe. Både Bibelfortellinger, Tidslinjen og Saman med Jesus er tett på Bibelselskapet sine omsetjingar (NO78/11). ${ }^{13}$ Tindberg si Bibelfortellinger for barn er friare i gjendiktinga, men også han har ei forplikting på bibelteksten. Det kjem tydeleg fram bak i boka, der han viser kva for eit av dei ulike evangelia han følgjer (s. 201).

\section{HovudTENDENSAR：TRENGJANDE, MARginaliserte OG SEKSUALISERTE KVINNER}

Når NT skal forteljast i dei norske barnebiblane, er Jesus den viktigaste personen. Som i NT kretsar forteljingane rundt Jesu liv, dei under han gjorde, og til slutt hans liding og død. Der GT ofte framstiller ei rekkje ulike helteforteljingar, vert NT først og fremst ei forteljing om Jesus og dei tolv, Jesu venner, og ulike menneske som Jesus møter. Kvar finst kvinner i denne forteljinga? Tendensar i barnebiblane kan summerast i 3 hovudtendensar: framheving av audmjuke kvinner som

11 Til samanlikning finst ikkje desse forteljingane i bibelboka utgjeve av Verbum frå 2007, Fortellinger fra Bibelen. Om Jesus og om mennesker og Gud.

12 To overskrifter namngir spesifikt kvinner. Desse er «Gåva frå enka» og «Jesus hos Marta og Maria.» Tilsvarande namngjev to overskrifter menn: «Peters fiskefangst» og «Jesus vekkjer opp Lasarus.»

13 Kolofonteksten i Bibelfortellinger krediterer ulike omsetjingar frå Det norske bibelselskapet. 
treng tilgjeving, marginalisering av kvinner, og til slutt ein fråverande sensitivitet for nettopp kjønnskritisk perspektiv.

\section{Kvinner som vert tilgjevne}

Det er ikkje mange bibelske kvinner som får sine eigne forteljingar i barnebiblane, men dei finst. Av dei kvinner som vert synleggjort i barnebiblane, er syndige kvinner sentrale. To av dei nyaste utgjevingane, Tidslinjen og Saman med Jesus, har den same overskrifta i utvalet: «Gud tilgir.» I begge bøkene handlar forteljinga om ei anonym kvinne som treng tilgjeving, men det er faktisk ikkje den same bibelforteljinga som vert fortalt. Den eine er forteljinga om ei kvinne som salver Jesus (Luk 7,36-50). Den andre om kvinna som vart gripen i ekteskapsbrot (Joh 8,1-11). Begge forteljingane omhandlar ein syndar som vert tilgjeven, og får i dei respektive bøkene den same teologiske funksjonen: dei fortel om ein nådig gud.

Lat meg først sjå nærare på den eine forteljinga, om kvinna som salver Jesus (Luk 7), som finst i både Bibelfortellinger og i Saman med Jesus. I Bibelfortellinger har denne ei eiga overskrift «Kvinnen som fikk sine synder tilgitt» (s. 357) og er hovudsakleg ei gjenforteljing av Luk 7,36ff. I Lukas vert kvinna som kjem inn i huset til Simon, referert til som ein 'syndar' ( $\alpha \mu \alpha \rho \tau \omega \lambda$ ós $\left.^{\prime}\right)$ to gonger (vv. 37 og 39). Det norske bibelselskapet si omsetjing frå 2011 skriv: «en kvinne der i byen som levde et syndefullt liv.» I Bibelfortellinger vert kvinna først presentert som «en prostituert kvinne.» I tillegg vert farisearen sine tankar referert slik: «Hun er en hore, en syndig kvinne.» Dette er utbroderingar av bibelteksten (jf. v. 39), riktignok i tråd med tradisjonell tolking av kvinna si identitet. ${ }^{14}$ Ein kan likevel spørje seg kvifor slike tradisjonar vert tradert i ei bibelbok for ungdom? Meir problematisk er likevel måten Luk 8,1-3 er fletta inn mot slutten av forteljinga. Lukas 8,1-3 omtaler Maria Magdalena, Johanna og Susanna som ressurssterke kvinner i Jesu følgje. I bibelselskapet si bibelomsetjing frå 2011 får Lukas 8 ei eiga overskrift, 《Kvinner som fylgde Jesus.»15 I Bibelfortellinger er dette avsnittet altså inkludert, og på den måten innordna, i kapitlet om kvinna som fekk syndene tilgjevne. Bibelfortellinger nemner og berre Maria Magdalena av dei tre kvinnene. På den måten vert Maria Magdalena kopla på den tradisjonen som gjorde ho til nettopp ei prostituert. ${ }^{16}$

Den same forteljinga om kvinna som salver Jesus, finst og i utvalet til Saman

14 Sjå t.d. kommentaren til Luk 7,37, som føreslår at 'syndar' her er ein eufemisme for 'prostituert', Nolland 1989, s. 353).

15 Dette avsnittet har vore av stor betydning for forkjemparar for kvinnelege prestar. Og sjølv om det ikkje treng å tyde på at kvinner forlot heimane sine for å reise rundt saman med Jesus, er det heilt klart eit poeng for Lukas å seie at det var kvinner som fulgte Jesus, ved å støtte hans verksemd. Kanskje slike som Marta og Maria, ved å by på husrom og mat (Levine 2018).

16 Tradisjonen har også identifisert synderinna i Luk 7,36ff som nettopp Maria Magdalena (Gregori den store, tale i år 591). Den katolske kyrkja stadfesta faktisk i 1969 at Maria Magdalena ikkje var prostituert! For meir utfyllande tradisjonshistorie, sjå oppslaget «Mary Magdalene» (Beavis and Gilmour 2015: 329-330). 
med Jesus, med overskrifta «Jesus tilgir.» Teksten er knapp, og konkretiserer ikkje synda til kvinna, men framhevar at Simon veit at ho har gjort ting som er gale. Forteljinga er illustrert med ei knelande kvinne framfor Jesu føter. I boka finst og forteljingane om Marta og Maria, om oppvekkinga av Lasarus og om Jesus som vaskar føtene til læresveinane. I Johannesevangeliet (Joh 11-13) er forteljinga om Maria som salver Jesus og Jesu fotvasking er ein del av same forteljingssekvens. Slik sett kunne det altså vore nærliggjande å inkludere forteljinga om Maria som salver Jesus, framfor forteljinga om kvinna som treng tilgjeving. Det er altså tydeleg at det er tilgjevingsaspektet, og ikkje salvinga, som er ynskt formidla. Illustrasjonen av den knelande kvinna frå Luk 7 liknar illustrasjonen av Jesus som vaskar føtene til læresveinane. Slik vert Jesus si audmjuke handling kopla saman med den syndige kvinna frå Luk 7, i staden for Maria, som ikkje har slike syndige konnotasjonar.

Tidslinjen har også overskrifta «Jesus tilgir», men her er den altså kopla til forteljinga om kvinna som vart gripen i hor (Joh 8). Forteljinga er illustrert med bilete av ei knelande kvinne som dekkjer ansiktet med handa. På veg bort frå kvinna går to menn med steinar i hendene. Dei skuler mot Jesus. Tidslinjen er nært knytta til eit metodisk opplegg, med eit uttalt mål om at barn og unges livsforteljingar skal kunne inngå i den enkelte eller den store bibelforteljinga (Håkonseth 2005:9). ${ }^{17}$ Når temaet er tilgjeving, skal gutar og jenter altså finne fram til bilete av ei kvinne i rosa klede, knelande og utan ansikt. Sidan denne bibelen ikkje har med forteljingar om Jesu kvinnelege vener, som Marta og Maria, verken forteljinga i Lukas eller Johannesevangeliet, står denne forteljinga fram som ei viktig kvinneforteljing.

Forteljinga om kvinna gripen i hor viser seg å vere populær. Den finst og i Bibelfortellinger, der den er fletta inn i kapitlet «Jesus i Jerusalem» (s. 390). Alle bibeltekstane i dette kapitlet, med unntak av «kvinna gripen i hor, » er henta frå innleiinga til lidingshistoria hos synoptikarane, og er assosiert med Jesu siste opphald i Jerusalem, anten Matt 24-26 eller den dels overlappande sekvensen i Mark 12-14. Korleis kom forteljinga frå Joh 8 om kvinna gripen i hor inn denne konteksten? Matteus 26,6-13 (jf. Mark 14) fortel om ei anonym kvinne som salver Jesus med kostbar olje. Hendinga provoserer læresveinane på grunn av sløsinga med pengar, og vert fylgd av ein notis om at Judas bestemmer seg for å forråde Jesus (Mark 14,10; Matt 26,14-16). Den same overgangen vert attgjeven i Bibelfortellinger, men her er det forteljinga om kvinna som vart gripen i hor som vert provokasjonen som resulterer i Judas sitt svik. Slik vever Bibelfortellinger saman Matt 26 (vv.3-5 og 14-16) og Joh 8, og erstatter kvinna som salver Jesus med kvinna gripen i hor. Det er nettopp her den kulturelle assosiasjonen er

17 Målsetjinga er formulert slik: «Gi barn og ungdom ei forståelse av sin eigen plass i denne (i Bibelen som helhet), store fortellingen.» 
interessant. I det førre kapitlet finst riktignok Maria som salver Jesu føter (Joh 12), og element frå Matt 26 (sjå nedanfor) er overført til den forteljinga. Likevel, heller enn å ha nok ei salvingshistorie, rommar ein ei ny historie om kvinner som treng tilgjeving. Slik forsterker Bibelfortellinger koplinga mellom kvinne og synd..$^{18}$

Det er påfallande at både Tidslinjen og Saman med Jesus, begge bøker frå 2016, tematiserer «Guds tilgjeving» illustrert med ei knelande kvinne. Ingen av desse kvinnene har namn, og heller ingen vidare forteljingskontekst. Dei er først og fremst kvinner, og vert slik personifiserte synderinner. Slik vert ikkje synda ei handling, snarare ein identitet. Desse to forteljingane (Luk; Joh 8) făr altså same funksjon i tre av dei fire bibelbøkene.

\section{Marginalisering av påskens og pinsens kvinner}

Kvinner har ikkje ei sentral rolle i Den nye testamentet si gjengjeving av hendingane i Jesu siste opphald i Jerusalem, men Luk 8,1-4 namngjev som nemnt fleire i Jesu følgje: Maria Magdalena, Susanna og Johanna. Det er desse kvinnene frå Galilea som dei ulike evangelia refererer til gjennom lidingshistoria (Luk 23; Mark 14,15,40.47; Matt 27,55.61). Og truleg er det og desse kvinnene som vert referert til i pinseforteljinga, saman med Maria og dei andre disiplane (Apg 1,14; 2,1). Sjølv om ikkje Luk 8 nemner Marta og Maria, vert desse systrene eksempel på slike kvinner som opna heimen for Jesus, og tok til seg Jesu lære. Markus og Matteus nemner ei kvinne som salver Jesus (Mark 12 og Matt 26) før lidinga tek til. I Johannesevangeliet er det Maria, syster til Marta og Lasarus, som blir berar av denne forteljinga. Også andre kvinner vert nemnt som vitne til hendingane mot Golgata, men evangelia gjev ulike namn. Berre Maria Magdalena er gjennomgåande hos alle evangelistane, og slik forblir ho også nemnt i dei fleste versjonane som vitne til Jesu oppstode.

Skal ein summere opp presentasjonen av påskens og pinsens kvinner i barnebibelutvalet, er funna ganske eintydige, og kan summerast slik: i) Kvinna som salver Jesus vert nedprioritert ii) Kvinnene ved grava er anten ikkje introduserte eller dei er anonymisert og iii) pinsen handlar hovudsakleg om disiplane som får Den Heilage Ande.

\section{(i) Kvinna som salver Jesus}

Det er berre ei av dei fire bøkene som har med ei salvingsforteljing der kvinna som salver, ikkje vert framstilt som synderinne. Bibelfortellinger har som vi har sett med forteljinga frå Luk 7, men fortel også at Maria, syster til Marta og

18 Det er neppe tilfeldig at kvinna som er gripen i hor (Joh 8), også dukker opp i ein liknande narrativ sekvens i Børnebibelen, knytta til Jesu siste besøk i Jerusalem (Møllehave 2017: 243). 
Lasarus, salvar Jesus i forbindelse med påskehøgtida. ${ }^{19}$ Etter kapitlet «Marta, Maria og Lasarus, » som omhandler systrene frå Lukas 10,38-42 og er sett saman med forteljinga om korleis Jesus vekkjer deira døde bror (Joh 11,1-44), kjem kapitlet «Inntoget i Jerusalem,» som tek til med at Maria salver Jesus. Bibelfortellinger presenterer her ein sekvens delvis basert på Matteus- og delvis Johannesevangeliet. ${ }^{20}$ Slik begynner på mange måtar Bibelfortellinger i Johannes-evangeliet med fortelijnga om Maria, men følgjer likevel Matteus 26. Der Maria ifølgje Joh 12,3 salver Jesu føter, noko som kan tolkast som eit frampeik på den fotvaskinga Jesus gjer (Joh 13,5), fortel Bibelfortellinger at Maria salva Jesu hovud (s. 385) jfr. Matt 26,7. Også andre element frå synoptikarane kling med: «Sannelig jeg sier dere: Hvor enn i verden evangeliet forkynnes, skal det snakkes om dette hun nå gjorde (...)» (Matt 26,13). Denne rekontekstualiseringa vert eit forteljingsgrep som ofte underst $\emptyset$ tter denne bibelen sitt prosjekt, nemleg å framheve kvinner. Likevel er det påfallande korleis kvinneperspektivet likevel taper terreng for dominerande forteljingstradisjonar, også i denne bibelboka. Det viktigaste eksempelet er som vi har sett, paradoksalt nok nettopp erstattinga av kvinna som salvar Jesus (Matt 26, 13) med kvinna gripen i hor (Joh 8) i kapitlet Jesus i Jerusalem. Sjølv om salvings-forteljinga vert fortalt i tilknytning til Maria, vert resultatet ein hybrid mellom ei salvings- og Mariaforteljing, til fortrenging av den synoptiske tradisjonen.

\section{(ii) Kvinner ved grava}

I barnebiblane dukkar kvinner opp i hovudsak først etter Jesu død og ofte utan namn. Dei vert introdusert som 'kvinner' og er vitne til Jesu oppstode. Mange av barnebiblane er nær synoptikarane, men flettar likevel inn forteljingar frå Johannesevangeliet, særleg Lasarusforteljinga og Jesus som vaskar føtene til disiplane. Det er påfallande at sjølv om ein følgjer Johannesevangeliet og har med Lasarus-forteljinga, betyr ikkje dette at ein har med Maria som salver Jesu føter.

Tidslinja er den einaste boka i utvalet som ikkje nevner Maria Magdalena, og som anonymiserer kvinnene ved grava. Kvinner er totalt sett ikkje underrepresentert i Tidslinjen si attforteljing, men ingen kvinner vert eksplisitt framstilt som Jesu venn, disippel eller etterfølgjar, t.d. finst ikkje Marta eller Maria i utvalet. I illustrasjonane er og kvinner ofte teikna utan ansikt, med ryggen til, eller med augo att. Særleg påfallande er dette i kapitlet «Jesus forkynner» (s. 122-123), der kvinner i folkemengda er spøkelsesaktige skikkelsar, medan menn er teikna med ansikt, eller med konturar av ansikt. I Tidslinjen handlar påskeforteljinga om Jesus som rid inn i Jerusalem, og folkemengda sin respons (Luk

\footnotetext{
19 I Johannesevangeliet startar lidingshistoria først i kapittel 18, men forteljinga om at Jesus vekkjer opp Lasarus (Joh 11), at Maria salver Jesu føter (Joh 12) og Jesu fotvasking (Joh 13) er tett assosiert med påskeforteljinga. 20 Riktignok er det Jesu føter som vert salva if. Joh 12,3. Er dette eit medvite forsøk på å likne synoptikarane?
} 
19), nattverden saman med dei tolv disiplane (Matt 26), Peter som fornektar og Judas som forråder, Jesus og Pilatus (Matt 27; Joh 18). Det er verdt å merke seg at kona til Pilatus som taler for Jesus ikkje er nemnt sjølv om ein følgjer Matteus 27, snarare tenestejentene som angir Peter (Jf. Matt 26,69-71). Maria, Jesu mor nemnes saman med læresveienen Johannes i forbindelse med korsfestelsen (s. 146), men kvinnene ved grava (Matt 28) făr ikkje namn (s. 344). ${ }^{21}$ Illustrasjonen viser to kvinner ved grava som har ryggen til. Tidslinjen gjev ikkje namn, viser ikkje ansikta deira, og gjev heller ingen vidare forteljingskontekst for kven dei er.

Saman med Jesus er som nemnd ein slags oppfylgjar av Bibelboka mi (2005) og må sjåast i lys av denne med tanke på utvalet i lidingshistoria. Dei tradisjonelle påskeforteljingane finst i Bibelboka mi, men her får vi supplerande forteljingar frå Johannesevangeliet som dannar ein sekvens frå «Jesus vekkjer opp Lasarus» (Joh 11) til «Jesus vaskar føtene til læresveinane» (Joh 13). Men Maria som salver Jesus føter (Joh 12), er ikkje med.

Påskeforteljinga i Bibelfortellinger for barn er strukturert med kapittel etter det vi kan kalle den kulturelle påskeforteljinga sin kronologi. Den begynner med 《Palmesøndag,» «Jesus i templet,» «Den stille uken,» «Skjærtorsdag,» «Langfredag» og «Første påskedag.» Disiplane speler ei sentral rolle. Kapitlet «Jesus i templet» identifiserer dei tolv som vennene til Jesus, eller «disippelflokken, » Peter og Johannes, og dei øvrige ti, nemnes ved namn (s. 182). Dei bibelske kvinnene har ingen plass i denne boka, men i forbindelse med første påskedag høyrer vi om «tre av kvinnene som hadde fylgd Jesus» og «En av kvinnene, Maria Magdalena» (s 193). Utover dette får Longinus ei sentral rolle ved korset, ikkje Maria. Det er paradoksalt at Bibelfortellinger for barn, sjølv om det finst ein klar feministisk intensjon, faktisk stadfester tendensen til den kulturelle bibelen: I gjenforteljinga av NT skrivest det fram dei nye kvinnelege karakterane Joanna og Cora. Altså diktar ein fram nye jenter og kvinner i staden for å skrive fram dei som allereie finst. Slik vert eigentleg den mannlege dominansen i den kulturelle bibelen forsterka, på trass av den impliserte intensjonen. Kanskje fordi dei bibelske kvinnene som finst i det antikke bibelmaterialet $\mathrm{i}$ stor grad er ukjent i vår kultur?

\section{(iii) Pinse med disiplar}

Som med påske, kretsar pinseforteljinga rundt læresveinane. Der Apg 2,1 $(\mathrm{NO} 78 / 11)^{22}$ referer til alle som var samla då pinsedagen kom, presiserer bøkene i utvalet «alle disiplene.» No er eit ord som 'alle' sjølvsagt open for tolking,

21 Kvinnene er heller ikkje namngjevne i lærerveiledningsheftet, men omtales som «kvinnene ved graven» eller «De tre kvinnene» (s 350), 344-354.

22 Generelt har Bibelen 2011 eit meir kjønnsinkluderande språk. Det som i Bibel 78 vart omsett med «brødre,» heiter no «sysken.» I omsetjingane av Apg 2,1-3 er det likevel marginale skilnader. 
men Apg 1,13 fortel at Peter og Johannes, Jakob og Andreas, Filip og Tomas, Bartolomeus og Matteus, Jakob, son til Alfeus, Simon seloten og Judas, son til Jakob heldt saman i bøn, i lag med nokre kvinner og Maria, mor til Jesus, og brørne hans.» (Apg 1,14). Det står og at dei var samla i et hus i byen (Apg 1,13). Alle bibelbøkene i materialet, med unntak av Saman med Jesus, har element frå pinsen med. ${ }^{23}$ Bibelfortellinger fortel:

Da pinsedagen kom var alle disiplene $i$ Jerusalem, og de var samlet $i$ et hus $i$ byen. (...). Disiplene fikk se tunger som av ild (...) satte seg på hver og en av dem. De ble alle fylt av den hellige ånd, og de begynte å snakke på mange andre språk.»

(416, mi understreking)

Det forutgåande kapitlet «Kristi himmelfart, » fortel at «Maria, Jesu mor, hans søsken og noen kvinner» heldt saman med dei. Og informasjonen om at «de var samlet i et hus i byen» er henta frå Apg 1,13. Likevel er ikkje referansen til kvinnene med. Det er vanskeleg å tenke seg at 'disiplane' som nemning skulle omfatte også kvinnene her, sidan kvinnene i Bibelfortellinger elles vert presentert distinkt i forhold til nemninga 'disiplane'. ${ }^{24}$ Ordlyden i Bibelfortellinger smalnar altså perspektivet, og inkluderer berre 'disiplane' i forteljinga om korleis kyrkja mottek Den heilage anden.

Det same skjer i Tidslinjen. Her er det og vanskeleg å tolke bruken av disiplar som kjønnsinkluderande nemning. Det forutgåande kapitlet, «Utsendelsen,» fortel at Jesus var saman med disiplane i førti dagar, og er illustrert med to menn som vert sendt ut av Jesus. I pinseteksten vert det berre referert til disiplane: «For ti dager siden hadde disiplene vært sammen med Jesus på et fjell. (...). Nå var det høytid og fest i Jerusalem. (...) Disiplene var samlet på ett sted.» Sjølv om teksten berre omtaler disiplane, viser likevel illustrasjonen tre kvinner med eld over hovudet. Den eine, truleg Maria Jesu Mor, sit til bords med disiplane. Kanskje er illustratøren påverka av nettopp biletkunsten? Den ortodokse ikontradisjonen har ofte jomfru Maria sentralt i biletet. ${ }^{25}$ Maria har likevel ingen opphøgd rolle i illustrasjonen, og det er verdt å merke seg at der alle dei mannlege disiplane har augo opne, har både Maria og den andre kvinna augo attletne (s. 155-156).

Bibelfortellinger for barn har eigentleg ikkje ei pinseforteljing, men fortel likevel om sentrale element frå pinsa. Inspirert av Johannes 20,19-23 der Jesus pustar på disiplane, og seier «ta i mot Den heilage ande,» får vi denne scena:

23 I Saman med Jesus (s 62) er heller ikkje Maria eller andre kvinner med i påskeforteljinga, verken på bilete eller i tekst.

24 Jamfør omsetjingstradisjonen av Iovviã $v$ i Rom 16,7, som først i NO 2011 vart ansett å vere ein kvinneleg apostel, 'Junia,' og ikkje 'Junias' slik NO78 gjenga den greske teksten (Sjå t.d. Eldon 2005)

25 Sjå og ikonet «Den hellige Ånds utgytelse» (2001) i Askim kirke. Ikonet er malt av Hæge Aasmundtveit, som er tydeleg inspirert av den ortodokse ikon-tradisjonen. 
«Disiplene stod alene, men inni seg hadde de Guds pust, eller det vi kan kalle Den hellige ånd. Den fylte dem slik at de ble modige nok til å gå ut i hele verden og fortelle folk om Jesus.» Det er altså igjen disiplane, som elles vert referert til som dei tolv, som er mottakarar av Den hellige ånd. Etter dette vert forteljinga runda av med Ariel og Johanna, og bestemora som syng og bed kveldsbøn saman med dei på taket.

Skal vi oppsummere påskens og pinsens kvinner, er funna ganske eintydige: Ingen av bibelbøkene fortel om kvinnene i Jesu følgje (Johanna, Susanna og Maria Magdalena), eller dei gjentekne henvisingane til dei som fulgte Jesus frå Galilea i påskehøgtida. Når dei så kjem til grava, har dei fått ei marginalisert rolle. Unntaket er Bibelfortellinger, men her vert Maria Magdalena sortert under historia om kvinna som vart tilgjeven. I og med at barnebiblane ikkje presenterer kvinner som fylgde Jesus som disiplar, vert og 'dei tolv' synonymt med 'disiplane.' I lys av dette er det vanskeleg å tenke seg at nemninga 'disiplane' skal kunna oppfattast som andre enn dei tolv. Slik trumfer vår førestellingsevne av pinsen det som står i Apg 1,13-14, slik at ein ser for seg at det berre var dei elleve (tolv) som var samla.

\section{Ein tilpassa bibel for barn - behovet for justering}

Alle barnebiblane viser kontekstuell tilpassing med omsyn til målgruppa sin alder, både i format og innhald - utval av forteljingar, illustrasjonar, kapittelinndeling og forteljingsstil. Ingen av bøkene har parallellforteljingar, men lager ei harmonisering av evangelia slik at det vert ei einskapleg forteljing. Det siste tiåret har det klart vorte meir merksemd om å få fram bibelske kvinner. Vidare er det generelt sett stor merksemd kring bibelens «problematiske» og voldelege forteljingar. I så måte er det interessant å sjå kva som utløyser justeringsbehov i dei ulike bøkene. Når må ein tilpasse dei antikke tekstane?

I alle bøkene er vald og hemn tona ned, og problematiske ideal og scener justert i formidlinga for barn. Særleg viser dette seg i gjenforteljinga av GT sine forteljingar. Bibelfortellinger har med forteljinga om Lot, men toner ned dei relativt grove valdsskildringane (s. 37-38). Tidslinjen ligg også nær bibelteksten, men forteljingane er korta ned. Tidslinjen har med forteljinga om Daniel, og kutter ikkje ut straffescena mot slutten. Like fullt er skildringa dempa (s. 91). Saman med Jesus presenterer korte samandrag av bibeltekstar, snarare enn forteljingar. Omfanget er relativt lite, og i den grad boka er i berøring med såkalla vanskelege tekstar, ligg justeringar i det utvalet som er med og måten forteljingane er forenkla språkleg.

Kva så med kjønnsperspektiv? Korleis utløyser bibelens patriarkalske tendens justeringsbehov i barnebiblane? Bibelfortellinger for barn er den som er mest fri i forhold til form, og den einaste i utvalet som legg nye element til bibelen 
sine forteljingar. Bibelfortellinger for barn dikter fritt, og betrar kjønnsbalansen i forteljingane t.d. ved å ha ein snekker Rakel (s. 48), og barnet i forteljinga om Jesus som metter fem tusen heiter Cora (s. 171). Bibelfortellinger for barn gir og namn der Bibelen ikkje gjer det (s. 201). I attforteljinga av NT diktar som nemnt Tindberg fram nye skikkelsar og kompenserer med bibelens favorisering av menn. Likevel, lesaren høyrer ikkje om bibelens Marta og Maria. I og med det klassiske utvalet i boka, som vi har sett tidlegare, vert bibelens eigne kvinner fortrengt.

Alle bibelbøkene i utvalet ser ut til å ville fasthalde ein god og nådig Gud, og i gjenforteljingane av NT kjem den nådige Gud særleg tydeleg fram i møte med kvinner som vert klaga for seksuell umoral, dette gjeld hovudsakleg i Tidslinjen, Saman med Jesus og i Bibelfortellinger. Kvinners kopling til seksuell synd finst $\mathrm{i}$ bibelmateriale, men i barnebiblane er desse forteljingane overrepresentert. Det at desse forteljingane ikkje utløyser behovet for å tilpasse bibelen, meiner eg er å forstå som eit symptom på vår kulturs syn på kvinna. Men ikkje berre det. Det er samstundes eit uttrykk for lojalitet mot bibelen, slik den er tradert i vår kultur.

Bibel står i ei særstilling, som heilag tekst. For kyrkja er bibelen Guds ord, og sjølv i meir sekulære samanhengar vekkjer bibelens status ei form for respekt. Denne posisjonen viser seg i både ærbødighet og i blasfemiske tilnærmingar. For bibelen er ikkje berre eit objekt, den vert og tillagt subjektivitet på den måten at den har ein bodskap som ein bør vere lojal overfor. Så langt eg kan sjå, springer bibel-representasjonane i barnebiblane ut frå ein lojalitet overfor bibelen slik ein tenkjer den er, altså den kulturelle bibelen. Samstundes finst legitime omsyn, til dømes pedagogiske omsyn overfor målgruppa og sjangermessige omsyn til kommunikasjonssituasjonen. Desse ser ut til å spele på lag med dei teologiske. Men dei ideologisk-kritiske omsyna, og spørsmål knytta til gjenkjenning og bibelske førebilete for jenter, ser ikkje ut til å vere aktivert.

\section{Bibelen i kUlturen Og DeN KULtURelle bibelen}

Korleis ser då vår kulturs bibel ut? Spurt på ein annan måte: Kva bibel er det som vert konstituert i vår kultur? Barnebibelen er på mange måtar ei representasjon av nettopp bibelen i kulturen. Den vert laga i vår bibels bilde, og er stadig med å reprodusere idear om kva bibelen er og inneheld. I bibelen slik vi reproduserer den i barnebiblane, er kvinner marginale karakterar, og dei er statistisk sett oftare knytta til synd enn i bibelteksten sjølv. Desse tendensane finst ikkje berre i barnebiblane, men kjem til uttrykk i kulturen generelt. ${ }^{26}$ Eg har først

26 Eit døme på dette er bibelreferansene i den populære musikkmessa av Tore W. Aas, Oslo Gospel Choir: Gloria. I «Kyrie» vert to bibelforteljingar alludert, den eine er likninga om den bortkomne sonen, den andre er kvinna gripen i hor. Medan sonen kjem til uttrykk i 1. person «Jeg så meg selv og mitt svik, så det huset som jeg engang forlot. Jeg vil stå opp og gå hjem til min far. Men alt jeg eier er et ødelagt liv!, forblir kvinna objektivert: «denne kvinnen er en hore, vi vil se kroppen hennes, se henne blø...» (Aas 1996, 9-14). 
og fremst unders $\emptyset$ kt materialiseringar av bibelen. Sjølv om det har skjedd noko i det kollektive medvitet om å integrere kvinnelege skikkelsar i bibelbøker for born, er eit tydeleg trekk forsterkinga av patriarkalske verdiar og marginalisering av kvinneperspektiv. I Tidslinjen finst Rebekka og Rut i innhaldsregisteret over GT, og Jairus datter i NT. Likevel er kvinnene ved grava anonyme, og vi får ikkje høyre om Marta og Maria eller Maria Magdalena. Jesus ser ikkje ut til å ha kvinnelege vener.

Barnebibelens manglande kjønnsbalanse har heilt klart samanheng med at Bibelen sjølv er frå antikken, og er blitt til i eit patriarkalsk samfunn. Tradisjonelt har også bibelen blitt hovudsakleg forvalta i ein mannskultur som og har vektlagt mannlege religiøse førebilete. Men bibelfortellingane slik dei vert formidla i dag, er like mykje eit uttrykk for vår eigen kultur. Utvalet og tolkinga av dette er både uttrykk for ei tradering, og samstundes vår tids kultivering av dei bibelske tradisjonane. ${ }^{27}$ Dei seier noko om korleis bibelen blir forstått, og er med å prege bibelkunnskap i ein kultur med fallande bibelkunnskap. Antikkens forteljingar er altså ikkje lenger antikkens, dei er våre.

Den kulturelle bibelen er altså eit uttrykk for bibelkunnskapen i det kollektive medvitet. Den vert reprodusert i vår kultur, mellom anna som skrivne barnebiblar. Samstundes skjer ei overføring av våre verdiar på bibelen (Sjå og Bylund 2019 i dette nummeret av Prismet om dette). Det er dei forteljingane som best speler på lag med våre gudsbilete og vår oppfatning av kristne verdiar som først og fremst vert berarar av ideen bibelen.

I ein artikkel i Prismet (No 4/2018) viser Ellen Aasland Reinertsen korleis tre likningar går igjen i Den norske kyrkja si trusopplæring: Den barmhjertige samaritan, Sauen som ble funnet og en far som ventet. Hovudgrunngjevinga som vert oppgitt er at desse er særlig sentrale (Reinersten 2018: 267). Dette utvalet er i tråd med Gud gir - vi deler: Plan for trosopplœering i Den norske kirke (2010). I oversikten over dei såkalla kjernetekstane (s. 46-47) finst nemleg berre to av dei tre likningane frå Luk 15. «Kvinna og mynten» er ute. Likninga om kvinna som baker (Luk 20, 13-18) er heller ikkje med i utvalet. Det kan sjå ut som om tekstar med feminine gudsbilete ikkje når opp. Det er altså eit utval forteljingar som går igjen både i barnebiblar og i trusopplæringa, og slik opprettheld ein ein bibel som er fattig på kvinneperspektiv og feminine gudsbilete. Dette utvalet skjer sjølvsagt i ramma av ein historisk og kulturell kontekst. Det er desse som best uttrykker vårt bilete av Gud og vårt bilete av mennesket. Difor vert dei og oppfatta som pedagogisk enkle. Slike utvalsprosessar seier mykje om vår kulturs tradering av bibelforteljingane. Og det er samstundes dette utvalet i trusopplæringsplan og barnebiblar som bidrar til å produsere ein bibel i symbolsk forstand. Det er denne bibelen barnet møter i trusopplæringa, og som dei umiddelbart

27 Tradisjon og oppfinning - akkurat som vår samtid er det (Gadamer 2004: 270-290). 
vil gjenkjenne som bibelen. Denne har heilt klart element av nåtid, og kjernetekstar med menneskesyn som vi kan identifisere oss med. Denne bibelen, her omtala som den kulturelle bibelen, svarer på mange måtar til Yvonne Sherwoods bruk av termen 'liberal bible' om tolkingstradisjonar som støtter opp om liberale politiske syn. Ifølgje Sherwood finst ei utbreidd forståing av at vårt moderne samfunn og bibelen er på same side (Sherwood 2012: 6). Sherwood snakker om «liberal bible» i britisk og vestleg politisk diskurs. Den såkalla liberale bibelen er ideen om at bibelen representerer liberale og demokratiske vestlege verdiar (Sherwood 2012: 326). Noko av det same ser vi i norsk ordskifte, særleg i forbindelse med forståinga av Jesus som synest å representere våre eigne verdiar. ${ }^{28}$ I ei unders $\emptyset$ king gjort av IKO i haust, om bruk av bibelen i barnehagar med særleg formål, kjem det klart fram ei forstång av at Bibelen formidlar gode verdiar til etterfølging. Difor må barn få kjennskap til Bibelen (Aadland: under utarbeiding). Utfordringa med den bibelen barn vert eksponert for, er som vi har sett at den i liten grad rommer t.d. feminine gudsbilete, kvinnelege førebilete, og slik begrenser vår kulturelle førestillingsevne, både om Gud og menneske.

Ideen om at «våre kristne verdiar» er forankra i bibelen, er eit teologisk viktig poeng. Men det er jo ikkje slik at Bibelen i sin heilskap, umiddelbart formidlar kristne verdiar. Annleis er det sjølvsagt med den kulturelle bibelen, som eksisterer nettopp i kraft av at den formidlar våre verdiar. Og det er nettopp dette som er eit viktig poeng: Den kulturelle bibelen, slik vi forstår bibelen sitt innhald og verdiar, er på mange måtar ein projeksjon av vårt eige. Det er på denne måten at kanon i kanon er eit uttrykk for vår kultur. Samtidig er det også denne kanon $\mathrm{i}$ kanon som former vår kultur. Då er det påfallande at kvinnesynet $\mathrm{i}$ barnebiblane er slik det er. Når våre samtids-oppsummeringar gløymer profeten Mirjam, Anna i tempelet og Marta og Maria, er det ikkje nødvendigvis eit uttrykk for kvinneforakt. Mitt inntrykk er at årsaka finst i lojalitet til bibelen, det vil seie bibelen slik vi kjenner den. Bibelske kvinner har havna i «arkivet.» Eit spørsmål vi må stille oss, er likevel korleis dette svarer til våre verdiar?

\section{KonkLUSJON: KvinNa i DEN KULTURELle Bibelen}

I vår kulturs tradering av bibelen ser vi ein gjennomgåande tendens i det gjenfortalte bibelmaterialet: kvinner som treng syndstilgjeving er overrepresentert, og kvinner frå påske og pinse er underrepresentert. Desse tendensane er ikkje nødvendigvis eit direkte uttrykk for at kvinna blir vurdert som mindre interessant, eller mindre teologisk viktig. Snarare er det sannsynlegvis eit uttrykk for førestillingar om kva bibelen er, inneheld og representerer. Dei ulike norske bibelb $\varnothing$ kene i dette materialet er alle «tru» mot bibelen, slik den vanlegvis vert formidla, og kanskje kan vi difor seie at dei er tru mot den kulturelle bibelen.

28 Sjå t.d «Egelands to selvportretter» (Filtvedt og Møller 2018). 
Denne bibelen kan seiast å vere utvalet av forteljingar og tolkingstradisjonen av desse. Den kulturelle bibelen er eit uttrykk for ein nedarva tradisjon, men den er samtidig eit uttrykk for vår «kultivering» av tradisjonen.

Den kulturelle bibelen er ikkje ein statisk storleik. Naturleg nok finst ei vektlegging som er i tråd med ein luthersk teologi og tradisjon. I NT er Jesus og dei tolv dei viktigaste aktørane: Påsken er viktig, men først og fremst dei hendingane som involverer Jesus og dei tolv. Det at Jesus vaskar føtene til disiplane, er langt meir framme enn at Maria salver Jesu føter. Samstundes vil utvalet i dei ulike bibelbøkene sjølvsagt også spegle dei ulike målgruppene for boka. Det er påfallande at alle utgjevingane det siste tiåret ser ut til å ha eit $\emptyset$ nske om å løfte fram fleire kvinneforteljingar. Men det er likevel nettopp kjønnsperspektivet i desse bøkene som utgjer eit felles svakt punkt. Utgjevingane vitnar om ei manglande merksemd kring ideologisk-kritiske omsyn. Materialet viser at kvinneforteljingar i liten grad aktiverer behov for justering eller omskriving. Opphopinga av kvinnelege syndarar fanges ikkje opp som eit problem av våre kulturelle sensorar, sjølv i produksjon av bøker for barn. Dette er eit uttrykk for ein kultur med liten sensitivitet omkring kjønnsroller og stigmatisering. Det skulle ikkje overraske oss mykje, for det er jo nettopp det \#metoo handla om. Både marginalisering av påskens og pinsens kvinner, og overrepresentering av kvinner som syndarar, kan sjåast i samanheng med vår felles kulturs forvaltning av bibeltradisjonen.

Traderinga av bibelen er ikkje upåverka av den kulturelle konteksten, og historisk sett har den jo nettopp informert den. Ei slik rolle har vel neppe bibelen i dag. Det er betimeleg å spørje kva for ei sjølvforståing den kulturelle bibelen inviterer til. Eg er usikker på kor stor betydning barnebiblar har for barnet si sjølvforståing, men eg er ganske overtydd om at dette har noko å seie for barnet sitt syn på bibelen - også når det veks opp.

\section{LITTERATUR}

Aasmundtveit, Anne Kristin (2016) Tidslinjen. Oslo: Verbum.

Aas, Tore W. (1996) Oslo Gospel Choir: Gloria Oslo: Tamu.

Assman, Aleida (2008) «Canon and Archive» i Cultural Memory Studies. An International and Interdiciplinary Handbook. Berlin/New York: de Gruyter, s. 97-107.

Afset, Bente Mari (2011) «Jona som forbilde, karikatur eller speilbilde» i Prismet 62 nr. 3, s. 139-150.

Beavis, Mary Ann og Michael J. Gilmour (red.) (2015) Dictionary of the Bible and the Western Culture. Sheffield: Sheffield Phoenix Press.

Bylund, Lovise (2019) «Udvandringen fra Egypten er som et 17. majoptog uden bunader og flag. Børnebiblers interaktion med den kulturelle kontekst» i Prismet 70 nr. 2, s.109-124 
Crossley, James G. (2014) Harnessing Chaos: The Bible in English Political Discourse since 1968. London: Bloomsbury.

Crossley, James G. (2015) «The End of Reception History, a Grand Narrative for Biblical Studies and the Neoliberal Bible.» i (red.) Reception History and Biblical Studies. Theory and Practice. T\&T Clark.

Eldon, Jay Epp (2005) Junia: The first Woman Apostle. Minneapolis: Fortress Press. Filtvedt, Ole Jakob og Hilde Brekke Møller (3.08.2018) «Egelands to selvportretter» nrk.no/ytring/egelands-to-selvportretter.

Gadamar, Hans Georg (2004), Truth and Method. 2.utg revidert omsetjing av Joel Weinsheimer and Donald G. Marshall, London: Continuum.

Gunleiksrud, Kristin (2011) Bibelfortellinger Oslo: IKO-Forlaget.

Håkonseth, Asbjørn (2005) Tidslinjen. Lœrerveiledning. Oslo: Verbum.

Kartzow, Marianne Bjelland (2012) Destabilizing the Margins. An Intersectional Approach to Early Christian Memory, Eugene: Pickwick.

Kartzow, Marianne Bjelland (2010) '»Asking the Other Question': An Intersectional Approach to the Galatians 3:28 and the Colossian Household Codes, > i Biblical Interpretation 18, Brill, s. 364-389.

Kartzow, Marianne Bjelland (2008) «Trosopplæring, bibelbruk og gender-bending» i St. Sunniva 4/2008.

Kirkerådet (2010) Gud gir - Vi deler. Plan for trosopplæring i Den norske kirke. Oslo: Den norske kirke, kirkerådet.

Larsen, Kasper Bro (2019) «Børnebibelen som kulturelt erindringssted mellom kristenform og kulturkristendom» i Prismet 70 nr 2. s. 125-140.

Lerheim, Birgitte (2016) «Trosopplæring for Guds små prinsesser? Teologi, kjønn og læring i bibelbøker for barn», i Prismet 67 nr. 1. s. 19-34.

Levine, Amy Jill (2018) «Off the Road but on the Way. The Ministering Itinerary Rather Than the Itinerant Ministry of Jesus's Female Followers » konferansepaper, SBL Annual meeting, Denver CO.

Møllehave, Johannes med illustrasjoner av Charlotte Pardi (1996/2017) Børnebibelen. Genfortalt av Johannes Møllehave. København: Bibelselskabets Forlag.

Hilde Brekke Møller «The Power of Jesus. The Use and Significance of 'Jesus' in Norwegian Culture.» Keynote-foredrag på Nordic New Testament Conference, Reykjavik, 2018.

Nolland, John (1989) Luke Word Biblical Commentary 35a, Dallas: Word Book Publisher. Punt, Jeremy (2012) «The Other in South African Children's Bibles. Politics and (Biblical) Systems of Othering > i Text, Image, and Otherness in Children's Bibles: What is in the Picture? Atlanta: SBL, s. 73-98.

Saxegaard, Kristin Moen (2009) «Når Gud angrer - nesten. Gammeltestamentlige fortellinger fremstilt i norske barnebibler» Prismet $60 \mathrm{nr}$ 2, s.77-90. 
Scheehan, Jonathan (2005) The Enlightenment Bible. Translation, Scholarship, Culture Princeton: Princeton University Press.

Schüssler Fiorenza, Elisabeth (1988) In Memory of her. A Feminist Theological Reconstruction of Christian Origins. New York: Crossroad.

Sherwood, Yvonne (2012) Biblical Blaspheming. Trials of the Sacred for a Secular Age. Cambridge: Cambridge University Press.

Skeie, Eivind mfl. (2007) Fortellinger fra Bibelen. Om Jesus og om mennesker og Gud. Oslo: Verbum.

Stichele og Pyper (2012) Text, Image, and Otherness in Children's Bibles. What is in the Picture? Atlanta: SBL.

Tindberg, Svein (2017) Bibelfortellinger for barn. Oslo: Stenersen forlag.

Torgauten, Tor Ivar (2016) Saman med Jesus. Bibelboka mi 2. Oslo: IKO-Forlaget. 